\title{
Indonesian EFL Teacher's Ideologies of Lingua Culture
}

\author{
Ruly Morganna \\ Universitas Sebelas Maret \\ rulymorganna@gmail.com
}

\begin{abstract}
This study aimed at investigating the interpretation of linguaculture and its depiction in EFL learning based on Indonesian EFL teachers' ideologies. This study used an instrumental case study that purposefully engaged ten Indonesian EFL teachers as the participants. A semi-structured interview was assigned to garner the expected data. This study revealed that eight teachers, ones holding an essentialist ideology, interpreted lingua-culture as one language with one culture and depicted it into several characteristics including becoming nativelike English users as the goal, using natively authentic materials, framing communicative competence theory for use, and applying indirect cultural teaching. On the contrary, the rest two teachers, ones adhering to a non-essentialist ideology, interpreted lingua-culture as one language with multiple cultures and depicted it into some characteristics extending to becoming intercultural English users as the goal, using cross-cultural non-native English materials, framing intercultural communicative competence for use, and executing direct cultural teaching. As the implication, anchored in the nature of multiculturality of Indonesian students, this study promotes EFL teachers to hold the non-essentialist ideology for its sustainability. This study offers two conceptual frameworks vis-a-vis EFL lingua-culture ideologies. Of the two, there is only one scientifically considered ideal to fit the multiculturality of Indonesian students.
\end{abstract}

Keywords -EFL learning ideology, lingua-culture, multiculturality 


\section{INTRODUCTION}

Today, in the perspective of linguistics pertinent to English social functions which prevail, the status of English language per se has evolved into the world lingua franca (hereafter as ELF) (Fang, 2017; Jenkins, 2006; Kusumaningputri \& Widodo, 2018; Liu \& Fang, 2017; Seidlhofer, 2001). One primary account making a convincing case as regards the status shift of English language as mentioned in prior is that the users of English nowadays encompass all the world citizens, whereby they are split into three circles, on the basis of the countries they are originally derived from, as depicted by Kachru (1990) in his world English's model. The three circles are comprised of inner, outer, and expanding circle countries. The Inner circle countries are those whose people socio-functionally use English as their first language for instance UK, USA, Australia, and etc. The outer circle countries represent those whose people socio-functionally use English as their official second language, and amid them are Singapore, India, Malaysia, and so on. The expanding circle countries refer to those whose people sociofunctionally use English as their foreign language, and the countries in this category are such as China, Indonesia, Japan, and etc. Accordingly, the standpoint claiming that English is the language of mere its native speakers will not do justice to the nature of English in situ any longer. English in its origin nowadays certainly becomes the world people's language which is socio-functionally used differently. These world people are derived from a variety of cultures that underpin their worldviews respectively, so they are multicultural by nature (Byram, 1997; Byram, Gribkova, \& Starkey, 2002). Hence, to a broader view, when the world people use English as a medium of international communication, the nature of their multiculturality will lead to the presence of intercultural nuance in their communication. In other words, Internationally, English will be used within an intercultural dimension (Byram et al., 2002; Fang, 2017; Kramsch, 1998; Kramsch, 1993).

Grounded in the context of Indonesian citizens, the issue with respect to intercultural, or in the other term, cross-cultural communication is also substantive on account of the multicultural nature of Indonesian citizens. As one of the large archipelagic countries in the world, Indonesia is dwelled by about 250 citizens who originally come from a wide range of diverse cultures (Sukyadi, 2015). The nature of multiculturality possessed by Indonesian people as such even leads to a comparable intercultural use between English language as the international medium of communication and Indonesian language as the 
national one when the two languages are used by Indonesian people (Hamied, 2012). Interculturality becomes the key of their communicative framework for the use of both English and Indonesian language, and Hamied (2012) adds that this paradigm vis-a-vis intercultural communication should be the basis in running and developing an appropriate English education for Indonesian students.

Anchored in the nuance of multiculturality and interculturality appertaining to the English use amid Indonesian people, English which by law is legitimated as the first foreign language in Indonesia has sociofunctionally been growing to be an additional language. One of the factors influencing such growth is technological advancement (Lauder, 2008). The increasing use of English has become a part of the nature found in today's Indonesian generation, and this condition happens in a harmony and does not replace or have a negative impact on the increase of the national Indonesian language. Such increase of English use attests to the importance of interculturality playing a role as the communicative framework inasmuch as the vast and huge amount of English communication taking place through the use of technological-based media leads to a high frequency of encounter with multicultural people from different countries.

There were three major issues having been portrayed thus far. They refer to English as the world lingua franca in situ, English per se as an additional language pertinent to its social function shift in Indonesia, and de facto multiculturality as the fundamental nature of Indonesian people. The three issues respectively meet one important point corresponding to interculturality as the English communicative framework. Hence, if grounded in the essence of how English pedagogy should be systemized in Indonesia, it seems really ideal to exert an intercultural communicative framework as the basis of English as a foreign language (hereafter as EFL) learning. A lot of scientific works have been proposed by a range of related experts in dealing with the notion of interculturality in EFL learning. Some of them study the realm of intercultural communication (Byram, 1986, 1997; Byram et al., 2002; Deardorff, 2006, 2009; Fang, 2017; Hua, 2013; Leggett, 2014; Lidya, 2016; Liu \& Fang, 2017), and others study the area of intercultural language learning (Crozet \& Liddicoat, 1999; FitzGerald, 1999; Liddicoat, Papademetre, Scarino, \& Kohler, 2003; Scarino \& Liddicoat, 2009).

Given the interculturality as the communicative framework in EFL learning, there are two interrelated domains lying to be the initial 
sources of the EFL learning enactment. They are language and culture (hereafter as lingua-culture). Language represents English per se, and culture belongs to the framework in respect of how English is used. It is necessary for English teachers to comprehend in appropriate details about the proper concept of lingua-culture in EFL learning since exerting an inappropriate conceptualization or ideology associated with linguaculture in EFL learning potentially ends up with conflicting and results in meaningless learning. In order to capably create meaningful EFL learning, English teachers are required to discern some conflicting debates between the essentialist versus non-essentialist ideology, or in other terms, the modernist versus postmodernist perspective whose standpoints are derived from the different ways of viewing linguaculture in EFL learning (see the literature review section for the appropriate details corresponding to lingua-culture in EFL learning). Once English teachers understand the two opposite ideologies of EFL learning and avail themselves of selecting the appropriate choice convenient for the context of Indonesia, they will pave the way for an ideal preparation of meaningful as well as successful EFL learning that fits the needs and nature of Indonesian students.

Based on the given brief account concerning with the ideologies leading to the different views of lingua-culture in EFL learning, this study works on bringing the issue, lingua-culture, into the context of EFL learning in Indonesia by means of probing into the Indonesian EFL teachers' related ideologies. To reach meticulous investigations, this study garners the intended information by assigning the following research questions:

How do Indonesian English teachers interpret lingua-culture in EFL learning?

How do they depict their lingua-culture related ideologies in the implementation of EFL learning?

In the last section, the author provides a critical implication with grounding the garnered information pertinent to lingua-culture ideologies held by the Indonesian EFL teachers to the three existing natures which are comprised of the status of English as the world lingua franca, the growing social function of English as an additional language in Indonesia, and the nature of multiculturality had by Indonesian students. The provided critical implication will promote and persuade the sustainability of the lingua-culture related ideology that conforms to the aforementioned three natures. 


\section{THEORITICAL FRAMEWORK}

This section casts light on a number of salient premises which account for a quantity of important features addressed in this study. Those features fall into a couple of constituents which entail culture, language and how it relates to culture, learning and how it relates to culture, and lingua-culture paradigmatic views in EFL learning.

\section{Culture}

To be simply defined, culture is discerned like an ice berg wherein the smaller part can be seen, but the wider part is unseen. The portion of culture which is seen is generally aligned with some physical objects such as the remained legacies from the ancients. Hence, the inherited products found amid people living a certain community are valuably seen as a part of culture (Peck, 1998). In the meantime, the portion of culture which is unseen inclines to be more challenging to be understood in the light of its complexities. This unseen portion is depicted as the patterned behavior that is systematic as well as prevailing in a certain social community. The construction and development of such patterned behavior do justice to the conventions or the way people in a certain community live their lives and share otherness. In a deeper interpretation, that sort of pattered behavior begins to emerge and develop from the familial cirlcle, and it sets people to manage to deal with the social conventions which exist (Larson \& Smalley, 1972; Trivonovitch, 1980). If discerned meticulously vis-avishow it works, this patterned behavior encompasses a range of aspects extending to perceptions, thoughts, beliefs, institution, conventions, rituals, and the ways of living (Chastain, 1988; Kramsch, 1993; Lado, 1957; Liddicoat et al., 2003; Peck, 1998; Scarino \& Liddicoat, 2009; Trivonovitch, 1980).

\section{Language and How It Relates to Culture}

Before getting into how language relates to culture, it is of paramount importance to firstly address the shift of perspectives in defining language. The old paradigmatic view simply defines language as the codes that are arbitrary but systematic in use as well as play a role as the tool of communication. On the one hand, such definition is correct, but on the other hand, if anchored in the exact sense of language use in a real communication, such definition does not sound sufficient to draw on what language basically is in the context of communication (Liddicoat et al., 2003). In respect of the aforementioned language definition, a 
criticism comes to the sense of arbitrariness. The generalization of arbitrariness cannot cover the whole users of a language since it is very frequently encountered that one language is used by people originally derived from various socio-cultural communities. They will use that language arbitrarily merely based on the conventions prevailing in their own social community, whereas such conventions probably and most often differ from those of other social communities that also use that language. To sum up, the nuance of arbitrariness in a language use is not incorrect by nature but cannot make a convincing case for being overgeneralized to represent how language is used amid all the users. The presence of diverse cultural values owned by the users of a particular language leads to a conception that the arbitrariness of a language per se is motivated in use (Halliday, 1978).

Mulling over the growing definition of language per se, the most current definition of language explains that language is depicted as a social semiotic that people use to express, make, and interpret meanings (Halliday, 1978; Liddicoat et al., 2003; Scarino \& Liddicoat, 2009). Most of the academicians working with linguistics agree with conceptualizing language in such a way. Grounded in this definition, it is also vividly seen a natural relationship between language and culture. it seems obviously unique that the processes which occur while the language users are expressing, making, and interpreting meanings through language in an ongoing interaction run within the framework of culture inasmuch as the language users' cultural values and paradigms drive them when doing those processes (Scarino \& Liddicoat, 2009). When an interaction takes place, the meanings respectively shared by both the speaker and interlocutor represent their thoughts, concepts, or perceptions which principally signify their cultural values (Wardhaugh, 2006). Therefore, culture always has an impact on the interactions between the language users (Elmes, 2013), and technically language mediates the interactions that are naturally cultural in situ(Assemi, Saleh, Asayeshh, \& Janfaza, 2012). Furthermore, Kaplan (1966); and Wierzbicka (1986) accentuate that the encountered phenomena as regards the use of language in both spoken and written discourses are always relatively interwoven to the issues associated with culture and society. To sum up, the relationship between language and culture has been clearly identified wherein the use of a language is always framed by culture, and language itself plays a role as the mediator of culture since culture is expressed through language in an interaction. 


\section{Learning and How It Relates to Culture}

Before getting into viewing how learning and culture are related, it is also considered necessary to initially address the growing perspectives accounting for the nature of learning. As generally existing in the literature discussing about the learning theories, the nature of learning has been initiated to be explored since 1940s in that the popular learning theory at that time is known by behaviorism. This theory portrays that learning occurs in the orientations towards stimulus, response, and reinforcement. Notwithstanding, this theory does not seem sufficient to cover the complexities when a learning process takes place. The behaviorism theory is further criticized by the academicians adhering to the cognitivist theory in that the criticism emphasizes that merely controlling the observable behaviors will not give much help to understand what learning actually is. Fundamentally, there are a number of mental activities that happen within someone's mind insofar as learning goes on. The cognitivist theory postulates that the essence of learning per se fundamentally aligns with someone's mental processes that deal with absorbing, recognizing, and constructing knowledge by utilizing his/her prior knowledge. Thus, learning is the cognitive processes of knowledge construction.

However, the cognitivist theory merely views the occurrence of learning on the one hand, or only in the realm of mental processes. Such view still seems inadequate to capably generalize the exact occurrence of learning inasmuch as when a learning process takes place, there is a nuance of interaction established by an individual with others as well as the surrounding objects. Accordingly, a socio-cultural view of learning emerges to help elaborate how a learning process obviously occurs. In accordance with Liddicoat et al. (2003), learning is identified as the processes of constructing knowledge or insights and making meaning that someone executes wherein the processes fall into the following categories: the cognitive processes of knowledge construction so-called intra-individual processes and the socio-cultural processes of knowledge construction so-called inter-individual processes. The former draws on a condition in which learning is undertaken by mentally reorganizing, restructuring, and interpreting information. Someone will understand a set of new information by doing the aforementioned three processes along with mapping the new information into his/her existing prior knowledge. He/she in this sense will further acquire his/her own novel conception. The latter highlights 
that the processes of constructing knowledge while learning takes place, besides occurring within someone's mental processes, are also conditioned on the basis of the social contexts which prevail. The social contexts in this sense cover the presence of other people contributing to give input through interactions such as teachers or other students and also the existence of the surrounding objects which at some point also serve as the input such as books, learning materials, and learning media. Furthermore, to a broader view, social contexts also subsume the cultural, historical, and institutional setting. To sum up, intraindividually, learning copes with cognitive knowledge construction, and inter-individually, learning deals with social interactions with people and the surrounding objects. The abovementioned socio-cultural learning concept as explained by Liddicoat et al. (2003) basically starts out from the original notion derived from Vygotsky (1978). Other relevant views in connection with socio-cultural learning theory can also be discerned from the notions proposed by Ellis (2000) and Turuk (2008).

Let us now scrutinize how learning relates to culture. Within the learning processes as conceptualized in the socio-cultural theory, one of them is the sense of interactions established with the surrounding people and objects. The interactions themselves are fundamentally always cultural since the mediator the interactions is language. The objects mediated by a language within an ongoing interaction cover the speakers' perceptions, thoughts, ideas, concepts, opinions, and etc. By nature, all of those objects are cultural inasmuch as they are all constructed and developed on the basis of the cultural values and paradigms.

\section{Lingua-Culture in EFL Learning}

The opposing lingua-culture based ideologies, essentialist and nonessentialist, have been discussed by Kramsch (2013) in her review about the existing creeds vis-a-vis EFL learning. In her review, she refers the essentialist ideology to a modernist perspective and the nonessentialist ideology to a postmodernist perspective. Her review is initiated by the modernist perspective whereby culture is called a big $\mathrm{C}$ as the term referring to the products of literacy such as literature and arts commonly found in schools, and small c as the term referring to English native speakers' ways of living. The small c culture aligns with the popularity of communicative competence theory (Canale \& Swain, 1980; Hymes, 1972) and the application of communicative language teaching method. Here, once English is taught to students, the continuity 
of the learning process will be based on one language (English) and one culture (English native speakers' culture). This view makes students acquire English native speakers' culture by exposure and immersion, and it sets the goal of EFL learning to the mastery of native-like English competences. Subsequently, alongside the emergence of the $21^{\text {st }}$ century, there arises a new way of seeing lingua-culture in EFL learning. It is signified by the presence of the postmodernist perspective that defines culture as discourse and identity. As discourse, culture is defined as a social semiotic construction that is made during on-going communication. It portrays the process of striving for the third cultural position undertaken by two persons having different cultures who communicate with each other using English. In turn, as identity, culture is seen as the blueprint owned by the English users whereby the blueprint itself is brought from their familial and social communities.

Today, a lot of EFL educators agree with viewing culture under the postmodernist perspective by virtue of the following considerations: First, teaching English native speakers' culture by exposure and immersion is inaccessible (Crozet \& Liddicoat, 1999; FitzGerald, 1999; Kramsch, 1993). Second, targeting English native-like competences is not achievable since there has never been found any scientific finding supporting the presence of native-like English competences from both the second and foreign language learners (Byram et al., 2002). In turn, third, underlying EFL learning merely on the basis of English native speakers' culture does not help students increase their critical cultural awareness so that they do not possess a shield to cope with stereotype conflicts while communicating using English with people coming from different countries and having diverse cultures (Barrett, Byram, Lázár, Gaillard, \& Philippou, 2014; Byram, 1986; Kramsch, 1993; Liddicoat et al., 2003; Newton, Yates, Shearn, \& Nowitzki, 2010).

Instead of translating the notion of lingua-culture in EFL learning into one language and one culture as depicted in the modernist perspective, the postmodernist perspective interprets lingua-culture into one language (English) and multiple or various cultures owned by the English users. Anchored in the postmodernist perspective as such, a lot of theoretical shifts associated with EFL learning take place. They are such as the shifts from native-like English linguistic competence to intelligible and comprehensible linguistic competence (Jenkins, 2000, 2006, Kirkpatrick, 2008, 2010, 2011; Seidlhofer, 2005), from communicative competence theory (Canale \& Swain, 1980; Hymes, 1972) to intercultural communicative competence theory (Byram, 1997; 
Byram et al., 2002; Byram \& Parmenter, 2012), and from communicative language teaching method to intercultural language teaching method (Liddicoat et al., 2003; Scarino \& Liddicoat, 2009).

\section{RESEARCH METHODHOLOGY}

\section{Research Design}

An instrumental case study with assigning interviews was utilized to garner the data in association with the interpretation and depiction of the lingua-culture in EFL learning from the Indonesian English teachers' ideologies. The rationale behind the qualitative application of an instrumental case study was because this study purposefully probed into the expected data in order to gain the depth and particular qualities of the data rather than merely reporting a narrow generalization of the data. 10 English teachers having been taking their graduate study majoring in English education were purposively engaged as the participants. Some prevailing criteria beyond their involvement in this study extended to that firstly they were adequately experienced and knowledgeable appertaining to the primary issues that this study addressed; secondly they were accessible for the processes of interview; and thirdly they were voluntarily willing to join this study.

This study used an interview to solicit the details of the expected data. An interview protocol was utilized to save the list of the assigned important questions. In order to reveal the data pertinent to the Indonesian English teachers' interpretation of lingua-culture, the interview questions were oriented towards asking about the way lingua-culture in EFL learning was interpreted and the reasons beyond teaching under the interpreted lingua-culture. Furthermore, in order to obtain the data corresponding to the depiction of Indonesian English teachers' lingua-culture ideologies in the implementation of EFL learning, the interview questions were oriented towards asking about the means of setting the EFL learning goal, organizing the EFL learning input, setting the communicative principle of EFL learning, and teaching culture from the set communicative principle.

The data garnered from interview were analyzed by exerting Miles, Huberman, \& Saldana's (2014) interactive model of data analysis. In regard to the employed model, this study carried out four steps of data analysis whose processes referred to data collection, data condensation, data display, and conclusion drawing. As previously 
illustrated, the data collection relied on interviews. In turn, the garnered data were coded on the basis of the major themes with respect to the formulated research questions, and some meaningful sub-themes were also taken to represent the details of the findings. The condensed data were subsequently displayed through some conceptual charts, some quoted interview transcripts, and the related discussions that follow. Those processes were undertaken several times until the data credibility was appropriately reached. Once the data had been considered credible, the conclusion was then properly drawn.

\section{FINDINGS AND DISCUSSIONS}

This section presents the findings whose details are anchored in the following two issues: 1) the Indonesian English teachers' interpretation of lingua-culture in EFL learning, and 2) the depiction of their lingua-culture related ideologies in the implementation of EFL learning. The data in connection with each issue are displayed into conceptual charts, quoted interview transcripts, and some illustrative explanations corresponding to the displayed transcripts. The given transcripts have been properly and carefully selected to represent any similar information shared by other participants. This selection is considered necessary in order to conform to the limited space.

\section{Indonesian English Teachers' Interpretation of Lingua-culture in EFL Learning}

The data appertaining to the Indonesian English teachers' interpretation of lingua-culture in EFL learning emerged in two different views. They represented an essentialist ideology and a nonessentialist ideology. As revealed, of 10 teachers, 8 teachers held the essentialist ideology by orienting their lingua-culture interpretation to one language (English) that aligned with one culture (English native speakers' culture), and 2 teachers came up with the non-essentialist ideology with the oriented lingua-culture interpretation regarding one language (English) conforming to multiple cultures. The following conceptual chart indicates the opposing interpretations of linguaculture. 


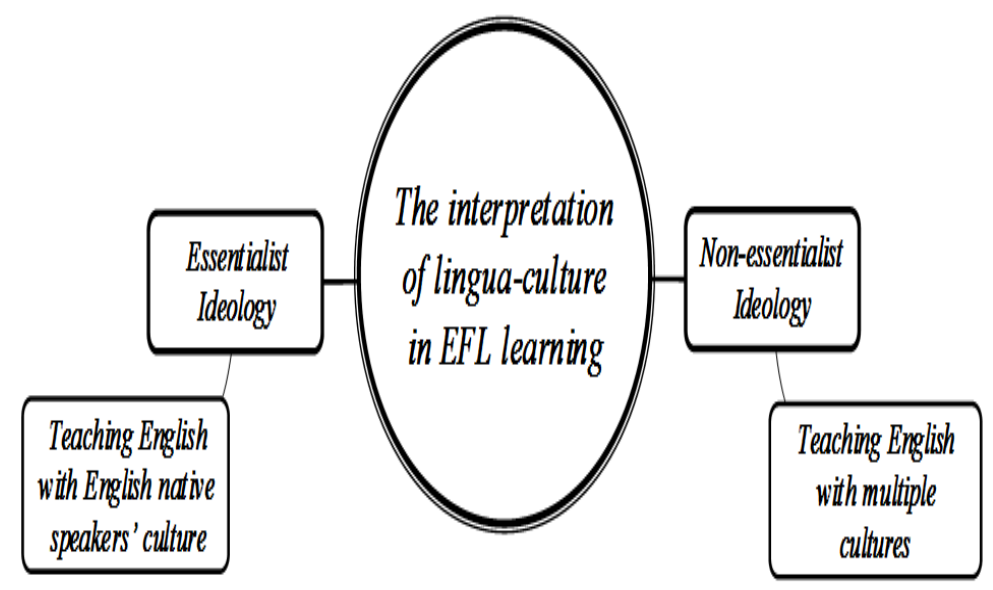

Fig.1. The Conceptual Chart of Lingua-culture Interpretation

\section{Essentialist Ideology}

\section{Teaching English with English native speakers' culture}

On the basis of the above chart, the following transcript of an interview with teacher 4 is selected to represent the lingua-culture interpretation had by all teachers adhering to the essentialist ideology. Interviewer How do you interpret lingua-culture in EFL learning?

Teacher 4 In my perspective, the essence of lingua-culture in EFL learning refers to teaching English language together with teaching English native speakers' culture. For example, when I was teaching English communication in the marketplace, I would also include the nuance of teaching some common conventions of selling or buying things as English native speakers do.

Teacher 4 in the above transcript illustrated her lingua-culture interpretation by representing the teaching of English language as well as English native speakers' culture at once. It was indicated by the shared example while she was teaching English communication in the marketplace. There was found one reason underlying the teachers' essentialist ideology regarding lingua-culture in EFL learning. It was to promote students to reach native-like competence. The following selected transcript of an interview with teacher 6 represents that reason. 
Interviewer Why do you teach English native speakers' culture only in EFL learning?

Teacher 6 I teach English native speakers' culture only to students because I really expect that my students will master English with native-like competence. Knowing English vocabularies, grammar and pronunciation only will not be enough for students to reach the level of native-like competence.

Corresponding to the above transcript, teacher 6 believed that the native-like English competence could not sufficiently be acquired by students if they were only faced with the learning of a mere linguistic competence. She believed that students also needed to have adequate efficacy regarding the use of linguistic-competence within the English native speakers' cultural framework. Thus, she came up with the importance of teaching English native speakers' culture alongside their linguistic competence.

\section{Non-Essentialist Ideology}

\section{Teaching English with Multiple Cultures}

Anchored in the chart, the transcript of an interview with teacher 3 bellow is sorted to represent the lingua-culture interpretation had by all teachers holding the non-essentialist ideology.

Interviewer How do you interpret lingua-culture in EFL learning?

Teacher 3 I think lingua-culture in EFL learning is indicated by teaching various cultures including ones belonging to students and ones beyond the English language itself. We need such concept because our students as nonnative English speakers will use English under their cultural framework. Even we, as their teachers, do the same way when using English. Thus, incorporating students' cultures and ones beyond English language itself is important in EFL learning.

Teacher 3 stressed her non-essentialist ideology on the linguaculture interpretation that extended to the teaching of English language and multiple cultures. She defined the notion of multiple cultures with the presence of cultures underlying the English language itself and the cultures owned by her students. She believed in the nature that non- 
native English users, like her students and also including herself as the teacher, used English on the basis of their own cultures. The nonessentialist ideology that teacher 3 took actually had several interrelated reasons. The following transcript indicates those reasons. Interviewer Why do you teach such multiple cultures in EFL learning?

Teacher 3 I teach both the cultures belonging to the students' environment and ones incorporated into the English language itself because I don't expect that students will have to lose or replace their own cultural identity when they are using English. I realize that such replacement has an impact on their psycho-social development. I also comprehend that one of the processes of knowledge or language acquisition needs to be mediated by the learners' own cultural framework so that they can be easier to acquire that knowledge or language. Therefore, teaching both the first and the second culture is important in EFL learning.

As portrayed in the above transcript, there were two reasons manifested beyond teaching English with multiple cultures. They referred to preserving students' own cultural identity from the foreign culture replacement and facilitating students to acquire English language more easily with using the students' own culture as the mediator of second language acquisition. Teacher 3 believed that the use of pure English native speakers' cultures as the mediator of English language acquisition would impede the success of acquisition since students were not familiar with the given cultural nuance.

\section{The Depiction of Indonesian English Teachers' Lingua-culture Related Ideologies in the Implementation of EFL Learning}

From the two diverging lingua-culture ideologies held by the 10 teachers, the further data addressed about the depiction of those ideologies in the implementation of EFL learning. The following conceptual chart briefly illustrates that depiction. 


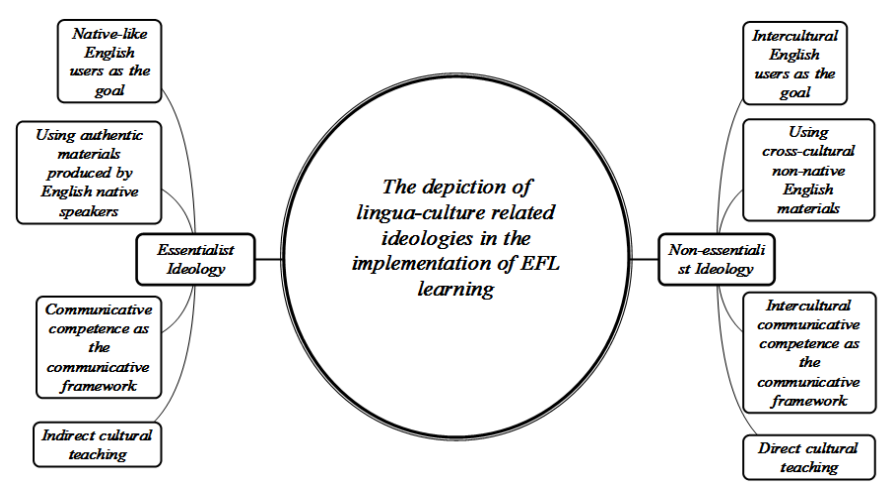

Fig.2.

The Conceptual Chart of the Lingua-culture Depiction in EFL Learning

\section{Essentialist Ideology}

Native-like English Users as the Goal

Anchored in the essentialist ideology, the 8 teachers agreed with targeting the mastery of native-like English competences, or becoming native-like English users, as the goal in EFL learning. The following transcript of an interview with teacher 1 is selected to represent this view.

Interviewer How do you set the goal of EFL learning beyond your lingua-culture related ideology?

Teacher 1 Concerning with the goal of EFL learning, I think, the most appropriate goal to be set is the mastery of English native speakers' competence such as the English competence had by American or British people.

Teacher 1 considered that the most ideal goal of EFL learning should be to facilitate students to master the native-like English competences, or in other words, to be native-like English users. She exemplified the intended competences to the use of English varieties owned by American or British people.

\section{Using Authentic Materials Produced by English Native Speakers}

The other important information shared by the teachers adhering to the essentialist ideology referred to the use of authentic materials in EFL learning. However, the authentic materials in their standpoint were only delimited to those thoroughly made by English native speakers. Such information is manifested in the following selected transcript of an interview with teacher 5 . 
Interviewer How do you organize the EFL learning input beyond your lingua-culture related ideology?

Teacher 5 The input that I organize to be served to students is authentic English materials. These materials are ones made by English native speakers. For example, English native speakers' audio or video for the listening materials and texts written by English native speakers for the reading materials.

As shown in the above transcript, the materials, including the audio or video as well as the written texts produced by English native speakers, were considered the most appropriate types of the materials required to be prepared and given in EFL learning. This way aligned with the previously stated objective of EFL learning stressed on the mastery of English native speakers' competences.

\section{Communicative Competence as the Communicative Framework}

In order to lead students to capably use English like native speakers, the teachers with their essentialist ideology exerted communicative competence theory as the fundamental communicative framework to be nuanced in EFL learning. The following selected transcript of an interview with teacher 2 addresses this notion.

Interviewer How do you set the communicative principle in EFL learning beyond your set of lingua-culture related ideology?

Teacher 2 I adopt communicative competence theory as the primary principle of English communication that I assign to my students. For some details, this competence comprises 4 influential indicators. They are linguistic competence, sociolinguistic competence, discourse competence and strategic competence.

With respect to the above transcript, there were four substantial components incorporated into the communicative competence theory. They entailed linguistic, sociolinguistic, discourse, and strategic competence. Those components worked on the basis of one creed socalled English native speakers' cultural based communication. 


\section{Indirect Cultural Teaching}

The teachers holding the essentialist ideology taught English native speakers' culture indirectly from the exposure embedded in the learning materials and the systemized practice of English communication. Such condition is indicated by the following transcript of an interview with teacher 10.

Interviewer How do you teach culture from the assigned communicative principle on the basis of your linguaculture related ideology?

Teacher 10 I taught culture by giving input in the form of natural English as used by English native speakers. For instance, I gave my students a video showing American people who were communicating their daily routines. The nuance of such communication automatically represented the use of communicative competence theory. Through that example, it was also automatic that American culture was indirectly exposed to my students.

The indirect English native speakers' cultural teaching was applied through presenting a video containing American people who were talking about their daily activities. Such video was considered authentic since the contents aligned with English use in the first language setting as conformed to the creed of the communicative competence theory, and the exemplified English communication from such video also characterized all related components of the communicative competence theory.

\section{Non-Essentialist Ideology \\ Intercultural English Users as the Goal}

Anchored in the non-essentialist ideology, the 2 teachers agreed with targeting the mastery of intercultural communicative competence or becoming intercultural English users as the goal in EFL learning. The following transcript of an interview with teacher 9 addresses this notion.

Interviewer How do you set the goal of EFL learning beyond your lingua-culture related ideology?

Teacher 9 In my perception, the most logical and convenient set of the goal in EFL learning is to lead students to be 
intercultural English users because students will use English to communicate not only with English native speakers but also with non-native English speakers. Thus, they need to master English for cross-cultural communication.

Teacher 9 believed that the nature of using English is to communicate with both native and non-native English users. Such condition automatically went to a cross-cultural communication. Accordingly, she proposed that becoming intercultural English users was the most convenient goal of EFL learning.

\section{Using Cross-cultural Non-native English Materials}

To promote the intended goal, the English learning process needed to avail itself of exerting cross-cultural non-native English materials. Such condition is manifested in the following transcript of an interview with teacher 9 .

Interviewer How do you organize the EFL learning input beyond your lingua-culture related ideology?

Teacher 9 For the input, I prefer to set the English materials made by non-native English speakers who have good competences in using English within cross-cultural communicative settings. Such materials are really suitable for motivating my students to enhance their enthusiasm while learning English. For example: I often provide them with the input such as a video showing a communication between an Indonesian celebrity and his friend from America.

Teacher 9 relied on the English materials produced by non-native English users who were sufficiently competent in intercultural communication. She believed that such materials were more motivating for students since the materials portrayed the natural use of English as an international language whose users are multicultural. She exemplified one of such materials by giving students a video containing English communication undertaken by an Indonesian who had mastered the intercultural English competence with his American friend. The encounter of two different cultures was shown in the video. 


\section{Intercultural Communicative Competence as the Communicative Framework}

The teachers adhering to the non-essentialist ideology agreed with making the intercultural communicative competence theory as the assigned communicative framework in EFL learning. This condition is manifested in the following selected transcript of an interview with teacher 3.

Interviewer How do you set the communicative principle in EFL learning beyond your set of lingua-culture related ideology?

Teacher 3 After dealing with some theoretical update in relation to the learning of English as a foreign language, now I rely on using intercultural communicative competence because this competence potentially leads my students to master English in cross-cultural communication. I believe this communicative dimension always takes place anytime English is used by non-native speakers like my students. Thus, ICC is the most appropriate framework of communication that my students need for their success of communicating English.

Teacher 3 supported her students to have adequate efficacy in cross-cultural English communication by exerting the intercultural communicative competence (ICC) theory as the fundamental principle of English communication to be practiced. The reason underlying the use of ICC theory was that it served what her students required in order to successfully be engaged in English communication.

\section{Direct Cultural Teaching}

With respect to the enactment of cultural teaching beyond the nonessentialist ideology, the incorporated multiple cultures were taught directly in order for students to experience the sense of cross-cultural English communication. Since to sustain cross-cultural or intercultural communication needed some knowledge pertinent to the comparison of various cultures including students' own cultures, direct cultural teaching was deemed important to be carried out. Such condition is shown in the following transcript of an interview with teacher 3.

Interviewer How do you teach culture from the assigned communicative principle on the basis of your lingua- 
culture related ideology?

Teacher 3 Since there are some cultures that I include in EFL learning such as ones belonging to English native speakers and ones belonging to my students, they cannot be taught by immersion. I taught those cultures directly with leading my students to view the native speakers' cultures and compare those cultures with their own cultures. Then I assigned my students to practice English communication within the setting of different cultural encounter so that my students can learn how to maintain a successful communication when cultural differences are found during communicating English. I believe that such setting is what naturally happens in a real communication of English as an International language. In my perspective, English as an international language is not English with native speakers' varieties.

Teacher 3 believed that teaching cultures by immersion would not be meaningful for students to comprehend and experience crosscultural English communication. Thus, she came up with the notion of direct cultural teaching in order to facilitate students to actively and critically learn about the differences found between the English native speakers' cultures and the students' own cultures. Such direct cultural teaching process was then followed by practicing intercultural English communication. One of the underlying reasons as regards such cultural teaching was that teacher 3 believed in the condition whereby the International English use always took place within cross-cultural or intercultural communication due to the multiculturality of the English users.

\section{DISCUSSION}

This study found two diverging lingua-culture ideologies in EFL learning as shared by 10 Indonesian EFL teachers. 8 of them held an essentialist lingua-culture ideology, and the rest, 2 teachers, took a stance on a non-essentialist lingua-culture ideology. In line with the essentialist ideology, the teachers interpreted lingua-culture into one language (English) and one culture (English native speakers' culture). Such ideology was also called a modernist perspective as the term used by Kramsch (2013) in her review. In turn, anchored in the non- 
essentialist ideology, the teachers interpreted lingua-culture as one language (English) and multiple cultures (ones belonging to English native speakers and ones owned by the students). Such ideology was called a postmodernist perspective (Kramsch, 2013). If compared to the existing literature with respect to the most current views of EFL learning, a number of criticisms strike the essentialist ideology since this standpoint does not meet the nature of English as the world lingua franca (hereafter ELF) (Fang, 2017; Jenkins, 2006; Kusumaningputri \& Widodo, 2018; Liu \& Fang, 2017; Seidlhofer, 2001). The status quo of ELF addresses that the users are world citizens who are multicultural by nature (Byram, 1997; Byram et al., 2002). The nature of multiculturality beyond the users of English per se demands an EFL learning that deals with more than one culture, at least the students' cultures and the culture beyond the English language itself to be involved (Crozet \& Liddicoat, 1999; FitzGerald, 1999). The streams of theories related to EFL learning nowadays support the stance of the non-essentialist ideology that regards the presence of the multiculturality as the English users' nature and the interculturality as the nature of English communication.

Other data revealed in this study went to the depiction of linguaculture related ideologies in EFL learning. The teachers with the essentialist ideology depicted several characteristics of EFL learning. They entailed promoting students to be native-like English users as the goal, using native speakers' authentic English materials, framing English communication on the basis of the communicative competence theory (Canale \& Swain, 1980; Hymes, 1972), and enacting indirect cultural teaching in EFL learning. On the other hand, lingua-culture depiction shared by the teachers holding on the non-essentialist ideology extended to promoting students to be intercultural English users as the goal (Byram, 1997; Hua, 2013), using cross-cultural non-native English materials, framing English communication based on the intercultural communicative competence theory (Barrett et al., 2014; Byram, 1997; Byram et al., 2002), and executing direct cultural teaching in EFL learning. If grounded to the existing literature, in the same way as the previous arguments, a lot of criticisms come to the essentialist ideology. Such goal set in the essentialist ideology with respect to targeting the mastery of native-like English competences is not considered logically achievable since up to nowadays there is no any scientific proof about non-native English users who manage to master native-like competences (Byram et al., 2002). That is why lots of experts prefer to 
set EFL learning into the concept of intercultural communication (Byram, 1997; Byram et al., 2002; Fang, 2017; Hua, 2013), and to apply intercultural English learning approach (Crozet \& Liddicoat, 1997; Crozet \& Liddicoat, 1999; Liddicoat et al., 2003; Lidya, 2016; Scarino \& Liddicoat, 2009). Those experts agree with setting the goal of EFL learning in support of the intercultural communicative competence mastery because de facto English is used by multicultural world people. In addition, such communicative competence theory (Canale \& Swain, 1980; Hymes, 1972) as the communicative framework adopted in the essentialist ideology is criticized owning to its portrayal of communication that merely makes a case for the use of English by its native speakers having the same culture (Byram, 1997). Such concept basically does not meet the nature of Indonesian students who are nonnative and multicultural English users. It can be discerned that the criticisms given by the above experts towards the essentialist ideology end up with the promotion of sustaining the non-essentialist linguaculture ideology in EFL learning.

\section{CONCLUSION}

Corresponding to the data revealed in this study, of 10 Indonesian English teachers, 8 teachers hold the essentialist lingua-culture ideology, and 2 teachers adhere to the non-essentialist lingua-culture ideology in EFL learning. Those diverging standpoints extend to the differences in both the interpretation and depiction of lingua-culture in EFL learning. The teachers with their essentialist ideology interpret lingua culture as one language (English) and one culture (English native speakers' culture). On the other hand, the teachers with their non-essentialist ideology interpret lingua-culture into one language (English) and multiple cultures (those belonging to English native speakers and ones owned by the students). Furthermore, the diverging standpoints result in a diverse depiction of lingua-culture in EFL learning. The teachers with their essentialist ideology share some characteristics of EFL learning they agree with. They refer to becoming native-like English users as the goal, using English native speakers' authentic materials, framing the communicative competence theory for English communication, and enacting indirect cultural teaching in EFL learning. On the contrary, the teachers with their non-essentialist ideology agree with a couple of EFL learning characteristics. They extend to becoming intercultural English users as the goal, using cross-cultural non-native English materials, framing the intercultural communicative competence 
theory for English communication, and executing direct cultural teaching in EFL learning.

\section{REFERENCES}

Assemi, A., Saleh, S., Asayeshh, M. E., \& Janfaza, E. (2012). Culture within Language. International Conference on Language, Medias and Culture, 33, 78-82.

Barrett, M., Byram, M., Lázár, I., Gaillard, M. P., \& Philippou, S. (2014). Developing intercultural competence through education. (J. Huber \& C. Reynolds, Eds.) (Vol. 1). Council of Europe Publishing. F67075 Strasbourg Cedex.

Byram, M. (1986). Cultural studies in foreign-language teaching. Language Teaching, 19, 322-336. https://doi.org/10.1017/S0261444800011101

Byram, M. (1997). Teaching and assessing intercultural communicative competence. Frankfurt Lodge, UK: Multilingual Matters LTD.

Byram, M., Gribkova, B., \& Starkey, H. (2002). Developing the intercultural dimension in language teaching: $A$ practical introduction for teachers. Strasbourg: The Council of Europe.

Byram, M., \& Parmenter, L. (2012). The common european framework of reference: The globalisation of language education policy. Bristol: Multilingual Matters.

Canale, M., \& Swain, M. (1980). Theoretical bases of communicative approaches to second language teaching and testing. Applied Linguistics, 1. https://doi.org/10.1093/applin/1.1.1

Chastain, K. (1988). Developing second-language skills. USA: HBJ Publishers.

Crozet, C., \& Liddicoat, A. J. (1997). Teaching culture as an integrated part of language: An Introduction. Australian Review of Applied Linguistics, 14, 1-22.

Crozet, C., \& Liddicoat, A. J. (1999). The challenge of intercultural language teaching: Engaging with culture in the classroom. In J. Lo Bianco, A. J. Liddicoat, \& C. Crozet (Eds.), Striving for the Third Place: Intercultural Competence through Language Education ( $\mathrm{p}$. 113). Melbourne: Language Australia.

Deardorff, D. K. (2006). The identification and assessment of intercultural competence as a student outcome of internationalization at institutions of higher education in the 
United States. Journal of Studies in International Education, 10, 241-266.

Deardorff, D. K. (2009). The SAGE handbook of intercultural competence. Thousand Oaks, California: SAGE publications, Inc.

Ellis, R. (2000). Task-based research and language pedagogy. Language Teaching Research, 4(3), 193-220. https://doi.org/10.1191/136216800125069

Elmes, D. (2013). The relationship between language and culture. 鹿屋体育大学学術研究紀要, 46 , 11-17. https://doi.org/10.1111/j.1467-9280.2009.02412.x

Fang, F. G. (2017). World Englishes or English as a Lingua Franca: Where does English in China stand? English Today, 33(1), 19-24. https://doi.org/10.1017/S0266078415000668

FitzGerald, H. (1999). What culture do we teach? In J. Lo Bianco, A. J. Liddicoat, \& C. Crozet (Eds.), Striving for the Third Place: Intercultural Competence through Language Education. (p. 127). Melbourne: Language Australia.

Halliday, M. A. K. (1978). Language as social semiotic. The interpretation of Language andMeaning. London: Edward Arnold.

Hamied, F. A. (2012). English in Multicultural and Multilingual Indonesian Education. Multilingual Education, 1(English as an International Language in Asia: Implications for Language Education), 63-78. https://doi.org/10.1007/978-94-007-4578$0 \_5$

Hua, Z. (2013). Exploring Intercultural Communication. Exploring Intercultural Communication: Language in Action. https://doi.org/10.4324/9780203798539

Hymes, D. (1972). On communicative competence. (J. B. Pride \& J. Holmes, Eds.). Harmondsworth: Penguin.

Jenkins, J. (2000). The phonology of English as an international language. TESOL Quarterly. Oxford: Oxford University Press.

Jenkins, J. (2006). Current perspectives on teaching world Englishes and English as a lingua franca. TESOL Quarterly, 40(1), 157. https://doi.org/10.2307/40264515

Kachru, B. B. (1990). World Englishes and applied linguistics. World Englishes, 9(1), 3-20.

Kaplan, R. B. (1966). Cultural thought patterns in inter-cultural education. Language Learning, 16(1 2$), 1-20$. https://doi.org/10.1111/j.1467-1770.1966.tb00804.x

Kirkpatrick, A. (2008). English as the official working language of the 
Association of Southeast Asian Nations (ASEAN): Features and strategies. English Today, 24(2), 27-34. https://doi.org/10.1017/S0266078408000175

Kirkpatrick, A. (2010). English as a lingua franca in ASEAN: A multilingual model. Hong Kong: Hong Kong University Press.

Kirkpatrick, A. (2011). English as an Asian lingua franca and the multilingual model of ELT. Language Teaching, 44(2), 212-224. https://doi.org/10.1017/S0261444810000145

Kramsch, C. (1998). Language and culture. Oxford: Oxford University Press.

Kramsch, C. (2013). Culture in foreign language teaching. Iranian Journal of Language Teaching Research, 1(1), 57-78.

Kramsch, C. J. (1993). Context and culture in language teaching. Oxford: Oxford University Press.

Kusumaningputri, R., \& Widodo, H. P. (2018). Promoting Indonesian university students' critical intercultural awareness in tertiary EAL classrooms: The use of digital photograph-mediated intercultural tasks.

System, 72 ,

49-61. https://doi.org/10.1016/j.system.2017.10.003

Lado, R. (1957). How to compare two cultures. Ann Arbor University of Michigan Press.

Larson, D. N., \& Smalley, W. A. (1972). Becoming bilingual: A guide to language learning. New Canaan, C.N: Practical Anthropology.

Lauder, A. (2008). The status and function of English in Indonesia: A review of key factors. Makara, Social Humaniora, 12(1), 9-20.

Leggett, D. (2014). How to Develop Teachers ' Intercultural Communicative Competence in the 21 st Century Education. ASILE 2014 Conference, 1-6.

Liddicoat, A. J., Papademetre, L., Scarino, A., \& Kohler, M. (2003). Intercultural language learning. Australia: Commonwealth Department of Education, Science and Training.

Lidya, F. S. (2016). In pursuit of intercultural communicative competence: An investigation into English language policy and practices at a private university in Indonesia. Australia: Victoria University of Wellington.

Liu, J., \& Fang, F. (Gabriel). (2017). Perceptions, awareness and perceived effects of home culture on intercultural communication: Perspectives of university students in China. System, 67, 25-37. https://doi.org/10.1016/j.system.2017.04.003

Miles, M. B., Huberman, A. M., \& Saldana, J. (2014). Qualitative data 
analysis: A methods sourcebook. Thousand Oaks, California 91320: SAGE Publications, Inc.

Newton, J., Yates, E., Shearn, S., \& Nowitzki, W. (2010). Intercultural communicative language teaching: Implications for effective teaching and learning. Wellington, New Zealand: School of Linguistics and Applied Language Studies and the Jessie Hetherington Centre for Educational Research, Victoria University of Wellington.

Peck, D. (1998). Teaching culture: Beyond language. Yale-New Haven Teachers Institute. Retrieved from http://teachersinstitute.yale.edu/curriculum/units/1984/3/84.03 .06.x.html

Scarino, A., \& Liddicoat, A. J. (2009). Teaching and learning languages: A guide. Australia: GEON Impact Printing Pty Ltd. https://doi.org/10.4324/9780203082423

Seidlhofer, B. (2001). Closing A Conceptual Gap: The Case For A Description Of English As A Lingua Franca. International Journal of Applied Linguistics, 11(2), 133-158. https://doi.org/10.1111/1473-4192.00011

Seidlhofer, B. (2005). VOICE (Vienna-Oxford International Corpus of English). Retrieved from http://www.univie.ac.at/voice/

Sukyadi, D. (2015). The teaching of English at secondary schools in Indonesia. Secondary School English Education in Asia: From Policy to Practice, 123-147.

Trivonovitch, G. J. (1980). Culture learning and culture teaching (In Croft,). Cambridge, Mass: Withrop Publishers. Inc.

Turuk, M. C. (2008). The relevance and implications of Vygotsky's sociocultural theory in the second language classroom. ARECLS, 5, 244-262.

Vygotsky, L. (1978). Interaction between learning and development. Readings on the Development of Children. New York. https://doi.org/10.1016/S0006-3495(96)79572-3

Wardhaugh, R. (2006). An Introduction to Sociolinguistics. Blackwell Textbooks in Linguistics (5th ed.). 350 Main Street, Malden, MA 02148-5020, USA: BLACKWELL PUBLISHING. https://doi.org/10.1353/lan.2003.0268

Wierzbicka, A. (1986). Does language reflect culture? Evidence from Australian English. Language in Society, 15(3), 349-373. https://doi.org/10.1017/S0047404500011805. 